った。線毛超微細構造の異常は, dynein arme の両側 あるいは一側の欠損が43, central complexの異常が 7であった. 430 dynein armeの欠損のう方 central complex 異常合弁 1, peripheral linkage 欠損合弁 4 などもみられた。

Immotile cilia syndrome 怔気管支拡張を必ずしも
有しているものでなく，小児においても非常にまれな 呼吸器疾患であるとおもわれない. Kartagener 症候 群の発生頻度から類推すれば 1：15〜30.000というも のもある。

小児反復・遷延性呼吸器疾患にたいしては鼻腔から 肺胞までの一連の気道病変の検索が必要である。

\title{
4. 遅発性内リンパ水腫
}

\author{
司会 原 田康夫(広島大)
}

一側隼の既往をもつものにめまいが好発すること は，1971年に亀井らにより報告された。1975年に Nadol らおよびWolfson and Leiberman が, 先行す る高度内耳性難聴を有する患者で，年余を経てメニエ ール病に類似しためまいを起こすものがあることを報 告した。また Nadol らは，手術時の所見やその際採取 した内耳液などより，これらの病態に内リンパ水腫が 関与していることを推察している。その後, Suhuknecht が遅発性内リンパ水腫という概念をこれらの症例 に適用し，今日に至っている。

遅発性内リンパ水腫をきたす原因疾患としては，外 傷, 流行性耳下腺炎, 細菌性内耳炎など種々のものが 報告されているが，本疾患（あるいは症候群）は，そ の存在を知らないと診断に苦慮し，思わぬ混乱を招く ことが十分に考えら机る。

今回のパネルでは，まずその疾患概念について原田 が述べ, 平川勝洋氏に遅発性内リンパ水腫の成立機転, 内リンパ水腫の病態, 水腫よりめまい発症の機序につ いて解説してもらった，松崎充男氏には原因疾患別の 連発性内リンパ水腫の頻度や，一側性熊患者でめまい
を起こす症例の統計など疫学的なことについて発表し ていただいた，高橋正紘氏には主に病歴，病状，検査 所見などからの診断法について，さらに，鑑別疾患に ついても発表していただき，最後にメニエール病より も薬物治療に抵抗するとされる本疾患（症候群）の治 療に関しては二木隆氏に扝願いした。

以上のアウトラインを基に特に以下のことについて 討論した。

1）本疾患（症候群）の定義, 特に聴力障害の程度, 恥力障害からめまい発症までの期間

2）治療法，特に対側型について

3）両側型の患側の決定と治療法について

本疾患 (症候群) の剖検例の報告は少なくメニエー 儿病と同様にその病態については，不明な点が多い。 しかし, 本疾患（症候群）の上うな症状を呈する例が 存在することは事実である. 症例の蓄積が病態の解明, 治療法の開発，改善の最重要加最短の道々考光る。 会員諸氏に本疾患の概要をご理解頂ければ幸いであ る.

\section{（1）遅発性内リンパ水腫の診断}

高 橋 正 紘（慶大）

遅発性内リンパ水腫を診断する上で参考となる，従 来の報告例の統計的資料，自験例および問題点につい て述へた。

\section{1. 診断基準}

Shuknecht の定義によれば，遅発性内リンパ水腫と は原因不明あるいは既知の炎症・外傷の一側高度難聴 の発症後，年余を経て回転性めまいの反復あるいは良 聴耳の聴力変動を来す症候群である。この定義を診断 基準として用いる場合，高度難聴の程度，発症までの 期間，めまいの反復や聴力変動の程度をどこまで含め るかの問題が生じる。ささらに内リンパ水腫を客観的に 裹付ける検査をどの程度診断の条件とするかが問題と なる。

\section{2. 原因疾患}

国内外の報告例156例でみると，難聴の原因疾患は原

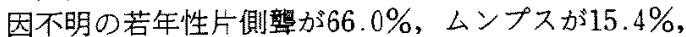
架発性難聴が $7.1 \%$, 麻疮, 頭部外傷が $3.1 \%$ の順とな つている. 原因不明とウイルス疾患を合わせると全体

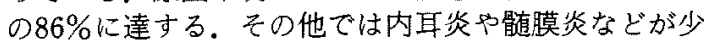
数例報告されている。

\section{3. めまい発症までの期間}

高度難聴発症後めまい出現までの期間は 5 年末満 が16.5\%，5-10年が14.8\%，10-15年が18.3\%で， 最初の 15 年で全体の $49.5 \%$ を占める。一方, 20 年以上 経過して発症した例も $42 \%$ 報告されており，本当に難 聴とめまいの間に因果関係があるかいなか疑問を抱か 
せる。

4. 温度刺激検查所見 (同側型)

記載のある127例では，難㯖側反応低下が59.1\%，両 側正常が $29.1 \%$ で全体のほほ $90 \%$ を占め，両者の割合 は2：1上なっている。この所見から 3 例に 1 例は温 度刺激反応が正常で患側決定の決め手に欠くことを示 している.

\section{5. 自験例の観察}

東京女子医大に招いて経験した同側型10例，対側型 4 例計14例の結果を報告した。来院時年齢は10歳から 65慽に及んでいた。難聴の発症年柃は 0 藏から25歳, 回転性めまい発症京での期間は 2 年から54年にわたつ ていた，原因疾患はムンプスが5例，中耳炎が1例， 他の8 例は不明（若年性片側㰍であった。めまいの 頻度はピーク時で 1 回/日から 1 回/年とばらついてい た。温度刺激反応は同側型，対側型を問わず，難聴側 低下が14例中10例と多数を占めていた。

症例の中には 8 歳でムンプスにより熊となり，10歳 より回転性めまいが始まり，めまい頻発のため高校を 中途退学した17歳女性がいた。しかし温度刺激反応は 両側正常で西り, 客観的証拠に欠けていた。さらに,
8 歳で原因不明の一側熋となり，30年後に他側の難聴 を伴う回転性めまい発作を繰り返した男性がいた。本 例では難聴側の温度刺激反応は正常で, 聴力変動側が 低下していた。このような例ではメニエール病の合併 を否定することができない。

全症例を通じ，欧米の報告例に比へ，投菜などでコ ントロールできる比較的軽症例が多かった。

\section{6. 診断上の課題}

今回の検討を通じ,診断をめぐり以下の課題が残った。 1) 成人例でメ二エール病合併といかに区別するか.2) 難聴からめまい発症（聴力変動）までの期間をどこま で取り込むか．3）どの程度のめまい・聴力変動を本症 とするか.4）めまいの患側沈定をいかにするか．5）力 ロリック所見と臨床所見が開離する場合，いかに対処 するか。

結局，遅発性内リンパ水腫と診断するためには，3 つの条件を考慮する必要がある.1）診断の必然性のあ ること(他の病態による説明が困難)，2）診断による 臨床上のメリットがある(予後推定, 治療方針)，3）診 断の客観性がある(内リンパ水腫を示唆する恰査所 見).

\section{（2）内リンパ水腫の病態について}

\section{平川勝洋（広島大）}

内リンパ水腫は, メ二エール病（突発性内リンパ水 睡）に特徵的な側頭骨病理所見であるが，迷路炎，側 頭骨骨折, 先天性内耳奇形队感音難聴患者の剖検例に も認めら机るものがある. Shuknecht 泳内リンパ水腫 在進行性内リンパ水腫と非進行性とに分け，進行性を さらに特発性(メニエール病), 内耳梅毒抢上び遮発性 内耳りンパ水腫に分類している。このうち漣発性内り ン八゙水腫は, 先行する高度感音難聴に年余を経てメ二 エール様のめまい発作就反復するもの（同側型）であ るが, その成立機転として, 以下の 2 条件が想定され ている.

1）螖牛機能を破壊する程度の内耳障害があるが，前 庭機能は温存されている。

2)内リンパ液の吸収に関与する組織（器官）の遅発 性の菱縮や線維化が序々に進行する。

Schuknecht は先行する一側性高度感音難聴患者 で，難聴側と反対耳の聴力変動を示す症例（めまいを 伴うことも古る) に対し，対側型荤発性内リンハ冰腫 の概念を提唱している。この場合の病態としては, 一
側の内耳機能（聴覚，平衡賞ともに）は廃絶あるいは 高度に障害され，対側耳に同側型と同様の障害が序々

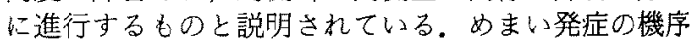
については，内リンパ水腫による限界圧あるいは圧上 昇速度説と膜迷路破裂説の $2 つ 0$ 説が現在のところ考 えられている。現在までに遅発性内リンパ水腫症例(同 側型，対側型ともに）の側頭骨病理の報告はなされて いない，前述の成立機転に関する説は推測のみである が，合理的であるのも事実である。一方，実験的に内 リンパ水腫を作製することは，内リン八整あるいは管 を機械的あるい住化学的に閉塞させることにより可能 である。しかし，実際のメ二エール病患者とは側頭骨 病理に，若干の相違がある。さらには実験的内リンパ 水腫動物とメ二エール病や遅発性内リン八゙水腫とは機 能的（聴力変動，めまい発作など）にも差がある.内 リンパ水腫形成までの期間については, 動物の種差に よる違いがあることも報告されており，よりいっそう の検討が必要でする。さらに, 本疾患の病態解明には 症例の蓄積が重要であると思われる。 